\title{
Military archaeology and contemporary reality in Albania
}

\author{
Armand Vokshi ${ }^{*}$, Elfrida Shehu ${ }^{2}$ and Sokol Dervishi ${ }^{3}$
}

\begin{abstract}
Heritage conservation provides economic, cultural and social benefits to urban communities. The building conservation role has changed from preservation to being part of a broader strategy for urban regeneration process and sustainable development. Heritage buildings are vital in for transferring the cultural identity for upcoming generations. Where heritage buildings can no longer function with its original use, proposing a new function is necessary to preserve the significance of the heritage building. This study aims to explore the fascinating dialogue between totalitarian regimes introduced in two museums adapted within the anti-nuclear bunkers in Tirana. The architectural projects of the museum aim to preserve the identity of their interior. While the careful architectural intervention is necessary to create the atmosphere of totalitarian ideology, in many cases we have to do with the continuity of existing architectural and urban elements in these particular projects. The work explores two museums, BuncArt 1 and BunkArt 2 , quite interesting reflection of the parts of history, during the years of world wars and the period of dictatorship of communism, with the facilities and elements exhibited there. In the meantime, thereafter, one can speak of a longer period for the period of the communist regime extending from 1945 to 1990. The impact of communist ideology, coming from the communist bloc of the East, also affects architecture and urban studies in Albania. In some respects, we have a silent follow-up to the monumental interventions that were made before the end of World War II. Another important element was the radical intervention in the bunkers in the territory and in the cities. Their quantity is considered with an amount of 700 thousand pieces. They were different in size and were seen more as defence-related parts rather than as a direct link to the new realist-socialist architecture. The return of some of them to the exhibition space was a good step to revitalize them. Currently they have been transformed into successful tourist attractions. Visitors come to perceive three important elements: (1) attractive military engineering, carried out in contrast to the challenges of the time, (2) the suffocating atmosphere during the communist dictatorship, which required extreme safeguards, (3) elements and historical facts of the World War period, as important elements during the Cold War. An ambitious third project, which is expected to be implemented in the future, is the conversion of the Pashaliman Naval Base in Vlora into another important military museum. This port was originally set up by mid-Fifties, by Russian troops, to have control over the Adriatic. The port is currently part of the military, thought to turn into a strong tourist pole.
\end{abstract}

Keywords: Memory, Military architecture, Bunkers, Cold War museum, Albania

\section{Introduction}

Rapid developments in terms of scientific and aesthetic values can take place in historical areas. Many values have been preserved and revived, while many others

\footnotetext{
*Correspondence: armandvokshi@gmail.com

${ }^{1}$ Faculty of Architecture and Urbanism, Politecnical University of Tirana,

Rruga Muhamet Gjollesha 56, Tiranë, Albania

Full list of author information is available at the end of the article
}

have been lost (Bullen and Love 2011). Adaptive reuse involves converting a building to undertake a change of use required by new or existing owners (Bullen and Love 2010), while conserving the architectural, social, cultural and historical values (Wilkinson et al. 2009), in order to not give wrong or missing information for the further generations.
Springer Open

(c) The Author(s) 2021. Open Access This article is licensed under a Creative Commons Attribution 4.0 International License, which permits use, sharing, adaptation, distribution and reproduction in any medium or format, as long as you give appropriate credit to the original author(s) and the source, provide a link to the Creative Commons licence, and indicate if changes were made. The images or other third party material in this article are included in the article's Creative Commons licence, unless indicated otherwise in a credit line to the material. If material is not included in the article's Creative Commons licence and your intended use is not permitted by statutory regulation or exceeds the permitted use, you will need to obtain permission directly from the copyright holder. To view a copy of this licence, visit http://creativecommons.org/licenses/by/4.0/. 


\section{Heritage conservation}

Conserving the character of suburbs and districts and reusing the old well-maintained buildings by using the new concept of adaptive re-use is the only way to conserve cultural heritage in its context. Heritage conservation, in turn, contributes to ecologically sustainable development (Latham 2000). The benefit of the adaptive use goes beyond sustainability and resource efficiency, including socio-economic factors driven by heritage and community interests, extending the economic viability of buildings and reducing maintenance costs (Cooper 2001). As such, rehabilitation of the historical buildings has some benefits which are:

i. Economic benefits: the spaces which are rehabilitated are more easily created than new spaces unless extensive structural reconstruction is required. A such, adaptive reuse avoids the process of demolition and reconstruction (Gosling et al. 2013).

ii. Environmental benefits; as the historical buildings are constructed using a range of quality materials (e.g. stone walls, marble floor coverings) the rehabilitation can bring the recycling of materials, reuse of structural elements and the reduction in generated landfill waste. Furthermore, many older buildings employ massive construction in their external envelope, which can reduce energy consumption in heating and cooling (Martínez-Molina et al. 2016).

iii. Social benefits: the intrinsic heritage values of the historical buildings are vital. In addition, they represent the memory of the society, and they can retrain attractive streetscapes, add character, and provide status and image to an organization through the use of massive and highly crafted materials (Wilkinson et al. 2009). Additionally, the adaptive reuse is seemed as a place attachment and motivational key force for the conservation of historic buildings (Stubbs 2004), as they aim to bind our roots, preserve the cultural identity (Tweed and Sutherland 2007) and improve the liveability of the city (Diamonstein 1978)

Cerreta et al. (2020) identifies the complex value chains generated by adaptive reuse, in which intrinsic values can play a driving role in the regeneration strategies of discarded cultural heritage. The experimentation, tested with the project "San Sebastiano del Monte dei Morti Living Lab" (SSMOLL), activates a creative and cultural Living Lab in the former Morticelli church, in the historic center of Salerno, in southern Italy. The results of the process show how a co-exploration phase has characterized the cultural characteristic of the living lab and how the co-evaluation of the individual activities orient the possible reuse scenarios.
Hasnain and Mohseni (2018) examine the role of branding as an innovative source of ideation in the implication of adaptive reuse on heritage. In this regard, the case study of Zalando outlet store in Berlin is selected, which is an old building situated in the commercial district of the city in a wide range of styles and heritage buildings from the middle ages. The findings indicate that the importance of the outlet building lies not only in its physical fabric or commercial aspects, but the spirit of the place that lies in the magical essence of big labels as emblems.

Yazdani and Wilkinson (2020) provide precise definitions and a holistic understanding of adaptive reuse and discusses complications related to the understanding of the concepts in the adaptive reuse of heritage buildings. The study applies a critical content analysis of published works related to genius loci and authenticity over time. The findings show the inter-relationship of genius loci and authenticity, and how these concepts can be considered in the adaptive reuse of heritage buildings, in theory and in practice.

Pintossi et al. (2021) provide a preliminary baseline of challenges faced by the city of Amsterdam from the perspective of various involved stakeholders and suggests solutions to address them. The participants represented the public, private, knowledge, and third sectors. The methods used were the following: for data collection, a multidisciplinary workshop using the steps of the Historic Urban Landscape approach as an assessment framework applied to multiple scales on adaptive reuse, and for data analysis, manifest content analysis.

Günçe and Misirlisoy (2014) explore the success of the adaptive reuse projects in terms of appropriateness of the museum function in a military establishment both in a conservation approach and museography approach. We selected castles will be compared in terms of use of military establishments as museums. The castles are selected from two different countries: Sforzesco Castle in Milan, Italy and Kyrenia Castle in Kyrenia, Cyprus which was used as castles before and are now converted to museums. The buildings are evaluated in two parts with the defined criteria: firstly in terms of conservation principles and secondly in terms of museography.

Hunter and Jateff (2016) study a post-military adaptive reuse of the Australian warship Protector while following a discussion of efforts to archaeologically document Protector's surviving hull and identify signatures of adaptive reuse indicative of its post-military career.

Misirlisoy and Günçe (2016) explore castles located in Cyprus and converted to museums. Four castles of the castles in Cyprus that have been converted to museums have been evaluated and compared in terms of the use of military establishments as museums. The selected 
castles were evaluated in two parts with defined criteria: firstly, in terms of conservation principles and secondly, in terms of museography. According to the results, generally the adaptive reuse projects have sustained the cultural identity of the heritage buildings; however, they have failed in bringing about efficient use and achieving socio-cultural benefits.

\section{Regeneration of military archeology}

The study considers some of the important open exhibition spaces in Tirana in the last 10 years, which have been dedicated to events during totalitarian systems in Albania. It is now well known that Albania's capital, Tirana, is a direct urban product of two dictatorial systems, the short Italian fascist occupation and the long communist dictatorship that ended in the 1990s. The architectural spirit of the fascist era created the new urban core of the city and during communism this core was consolidated and further expanded with new urban blocks of space in a real social style. Although a considerable part of the city developed during the Ottoman period remained intact, the city still transmits to a large extent the presence of the real socialist city (Vokshi 2020). In addition to the presence of the architectures of the two regimes, in the city of Tirana and beyond, museums especially associated with military facilities and espionage structures during the Cold War are necessary to be explored.

The common element between them is the topics they address, as well as the spaces in which they are located.

The present study analyses four typical museums focused on events during the Cold War:

a. Two underground museums, which are two antinuclear bunkers of the communist era, BunkArt 1 and BunkArt 2,

b. The museum of "The House of Leaves", which was a villa of the thirties, during the dictatorship turned into a place of espionage for dissidents and for Albanian intellectuals.

c- Unfinished project of the underground military port at Portopalermo, near Vlora, which was a military base for Russian submarines, built in the 1960s.

\section{Albania between the regimes}

It should be noted that Albania is an interesting case study in terms of linking the urban and architectural part with totalitarian systems. The presence of totalitarian systems is closely linked to the international developments of the twentieth century (reference). The independence of Albania was realized in 1912, after five centuries of occupation by the Ottoman Empire. In recent years there have been various dynamic developments from a historical point of view. In relation to all the Balkan countries, Albania is the only case where two totalitarian dictatorships are constantly following each other.

\section{Albania under Italian fascist troops}

In April 1939, Albania was militarily occupied by the Italian fascist troops of Mussolini, and this lasted until 1942. It is worth noting that, even before the military occupation, since 1924, during Ahmet Zog's dominance of Albanian politics, for a period of 15 years, Mussolini's government had a strong influence in the formation of the new Albanian state. This influence has not only had an impact on the economy and politics, but also on all walks of life. They were especially felt in urban planning, architecture, and art. The military invasion of 1939, which forced the Albanian king Ahmet Zog to flee, simply deepened the influence and dictatorship of the Italian fascist state in all areas of life in Albania (Biaggini 2005).

\section{The communist dictatorships}

The second totalitarian system that followed fascist domination is the communist system. It came directly after the end of the Second World War and lasted until the nineties (History of Army War Art 1989). The established dictatorship was an extension of the influence of the communist dictatorships of the Soviet Union and of the east bloc. This automatically brought about a new political, ideological, economic, and social approach to a system similar to that of the Moscow Bolshevik regime. However, Albania's long-term political and ideological course would only be determined by Enver Hoxha himself and other Communist Party members (Guxholli 1988). He was an Albanian communist politician who served as the Prime Minister of Albania, as the First Secretary of the Party of Labour of Albania, from 1944 until his death in 1985.

The years of the dictatorship are composed of several periods, which are divided according to different approaches, in which the dictator Enver Hoxha had in relation to his international relations. In 1947 Hoxha broke off relations with neighbouring Yugoslavia, ostensibly because the less hard-liner Yugoslavs were straying from the true path of socialism. Hoxha had a name for the state of preparedness all Albanians should be in-gjithmone gati, or "always ready". This state of mind came in part from his experiences in World War Two. Until the mid-1960s, his direct relations were with the Soviet Union and the Eastern Bloc countries. These links marked great progress in some aspects of industrialization, education, and the rise of the communist state. During his control of the country, Hoxha took radical steps in relation to other countries, banning religion, interrupting outward movements, and using his secret services 
against any opposition thought. Great empowerment was made especially by the military, exploiting the strategic position in that part of Europe that Albania represented in the eyes of Moscow (Guxholli 1981; Karaiskaj 1990; Fiçori 2015). A series of different military bases were set up throughout the country. While almost a quarter of the Albanian state budget went to the military, much of that funding was spent on building bunkers. At that time, a large system of bunkers of different typologies began to be built in every corner of the country (Engels 1976). The most widespread was the fungal model named "M22", the prototype built in the 1950s. The engineers had assured Hoxha that he would withstand a full onslaught by hitting a tank shell. Hoxha decided to give it a try, with the design engineer inside, and when he appeared unharmed by the attack, so began their mass production. Albania then lurched into another problem in 1961 after Hoxha declaimed Stalin's reform-minded successor Nikita Khrushchev. The Soviets and the rest of the Warsaw Pact froze Albania out, forcing the isolated state to align itself instead with Mao Zedong's China (Vokshi 2020).

This honeymoon, too, was short-lived. Incensed by Mao's welcoming of US president Richard Nixon to China in 1972, Hoxha rapidly cooled relations with the Chinese too. By 1978, the Chinese had withdrawn all their advisors, leaving Albania without allies-and the most isolated country in the world.

\section{The doctrine of Hoxha's military}

From the paranoid thoughts of the Communist nomenclature on the possible occupation by his former Soviet allies, or the USA and NATO forces, so many concrete and steel bunkers were built, with the aim of stopping a large army. The idea of protecting the country from the ground was the only military justice strategy of the time (Lleshi 2020). Bunkers sprout, like large gray mushrooms from the mountains north, south, and up the coastline, sprouting in any urban neighbourhood, or in the fields, between graves and beach umbrellas (Hutchings 1997). The doctrine of Hoxha's military hard line had led him to think that the NATO attacks would come from neighbouring Italy or Greece. But he also had other enemies, such as Tito's Yugoslavs, who in the forties had contributed to the establishment of the Communist Party in Albania. An invasion could come from the Yugoslavs themselves, or their country could be used as a war corridor for a Soviet invasion (Vokshi 2020).

Albania's armed forces would not be able to withstand a conventional battle against all these enemies, much stronger, in Hoxha's view (Dokument i deklasifikuar i Ministrise se Mbrojtjes se Shqiperise 1984). He called for the mobilization of all strata of the population, most of whom had to do basic military training each year. It was

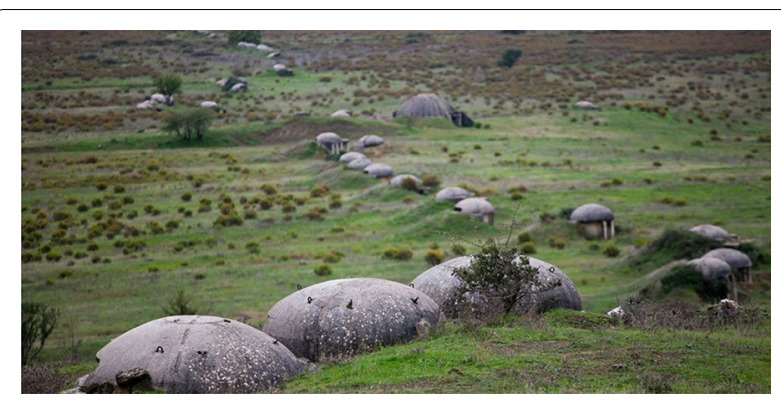

Fig. 1 Picture from the bunkers in Albanian territory

called "soft", and was a parallel form of resistance, alongside the real army. Taught in the days of the partisan war, where small units would carry out attacks on Italian or German outposts, descending from the mountain, the nomenclature coming out of that war, he wanted to ensure that every invader would face the same, creating a wide network of bunkers. The thought system was such that all people would fight every beach, village, and crossroads through the bunkers. Albania would become a land covered with these grey bunkers (Hutchings 1997).

\section{The bunkers}

The bunkers were standardized by the Albanian Army (see Fig. 1). They were built with concrete, steel and iron, and in size from fighting facilities for one or two persons with light weapons, to large underground shelters, intended to be used by the leadership of the party and the bureaucrats and to be protected from nuclear bomb attacks. Country bunkering could be divided into three main categories:

- Qender Zjarri ("firing position") or QZ bunkers (Fig. 2).

- Pike Zjarri ("firing point”) or PZ bunkers (Fig. 3).

- Large bunkers and tunnels.

\section{QZ bunkers}

The first category of the most used bunker (Shametaj 2004) is a small concrete dome set into the ground with a circular bottom extending downwards, just large enough for one or two people to stay inside. Known as Qender Zjarri ("firing position") or QZ bunkers, they were prefabricated and transported to their final positions, where they were assembled. They consist of three main elements: (i) $3 \mathrm{~m}$ diameter hemispherical concrete dome with a firing slit (ii) a hollow cylinder to support the dome (iii) an outer wall with a radius $60 \mathrm{~cm}$ larger than 


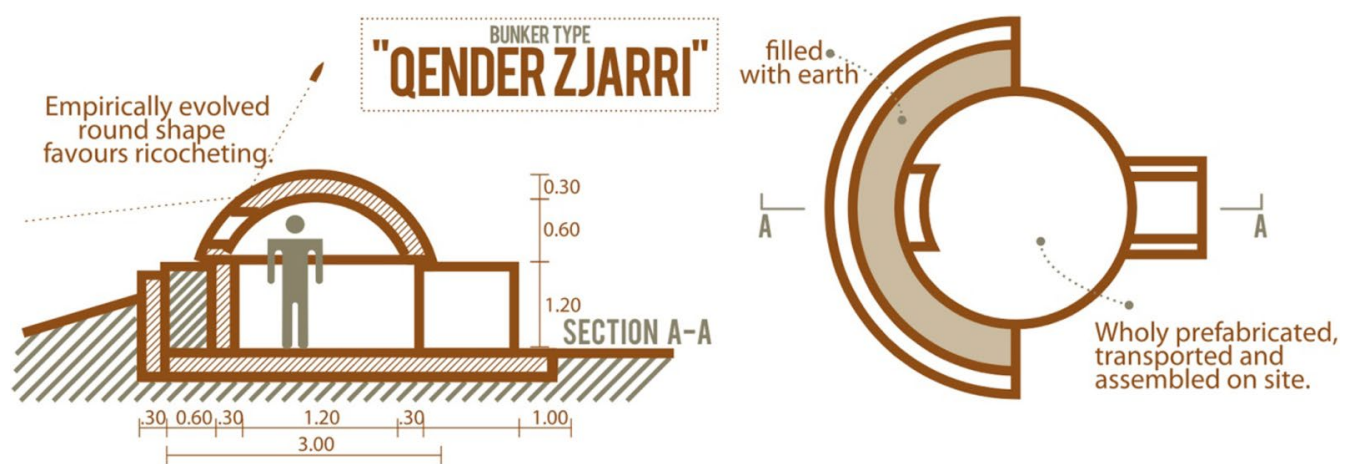

Fig. 2 Picture from QZ bunkers
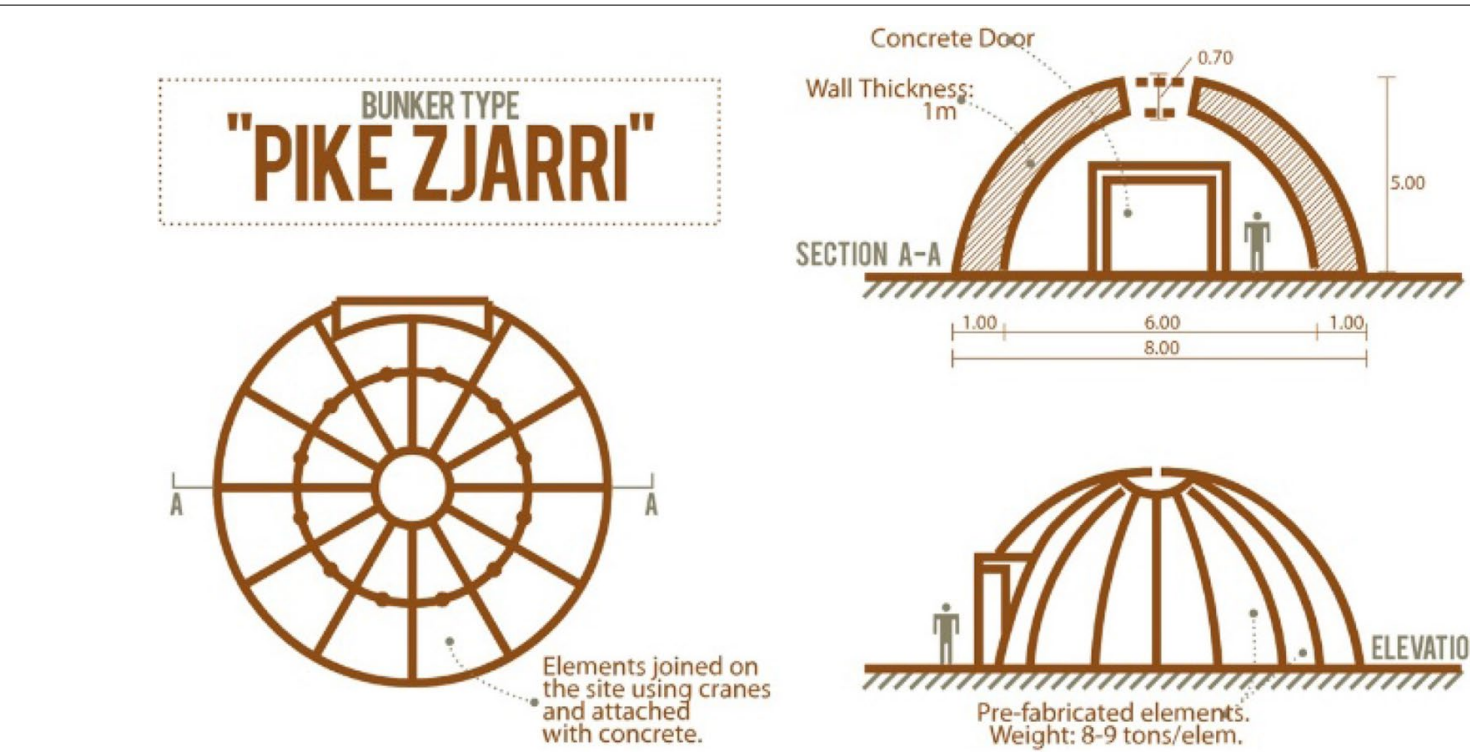

Fig. 3 Picture from PZ bunkers

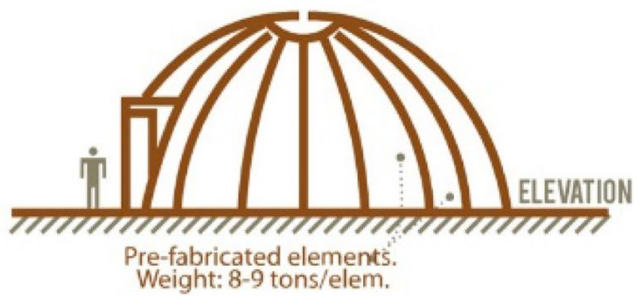

the cylinder. The gap between the cylinder and outer wall is filled with earth (Engels 1976).

At various places along the coast, large numbers of QZ bunkers were built in groups of three, linked to each other by a prefabricated concrete tunnel. Elsewhere bunkers were constructed in groupings around strategic points across the country, or in lines across swathes of territory. Tirana was particularly heavily defended, with thousands of bunkers radiating out in 50 concentric circles around the city.

\section{PZ bunkers}

The second category, the command-and-control bunkers, known as Pike Zjarri ("firing point") or PZ bunkers, were also prefabricated and assembled on site. They are far larger and heavier than the QZ bunkers, with a diameter of $8 \mathrm{~m}$. They are made from a series of concrete slices, each weighing eight or nine tons, which were concreted together on site to form an interlocking dome. Fully assembled, they weigh between 350 and 400 tons.

\section{Tunnels}

The third category of larger "special structures" is for strategic purposes. The largest were bunker complexes tunnelled into mountains. At Linza near the capital, Tirana, a network of tunnels some $2 \mathrm{kms}$ long was built to protect members of the Interior Ministry and the Sigurimi (the secret police) from nuclear attack. Elsewhere, thousands of kilometres of tunnels were built to house political, military, and industrial assets. Albania is said to have become the most tunnelled country in the world after North Korea (reference). The tunnels were built in 
conditions of great secrecy. Engineering teams were not allowed to see construction through to completion but were rotated from site to site monthly (Agolli 2012; Golloshi 2010; Fabrizio and Maria 2010).

\section{Contemporary reality of bunkers and military bases in Albania}

Bunkers and military bases entered daily life with their presence for the Albanian citizens, who watched in their windows at every corner, even though the long-awaited enemy never came. Decades after the end of Hoxha's totalitarian regime, bunkers still dominate the landscape in some places. This important presence in the territory, as a strong historical relation, but also panoramic relevance, is the basic starting point of our research methodology. A spontaneous civic tradition has already been established, which is related to the regeneration and use of these important sites, as well as the large quantities of other parts displayed everywhere in Albania.

All these interventions converge on some common points:

- Potential impact on the protection of landscapes and the sustainable development of persons involved in territories.

- The internationalization and the international dimension of this heritage, trying to be as original and at the same time, finding connections with other examples or scientific networks.

While some have been turned into hotels, restaurants, or residential homes by some creative citizens, most have been abandoned and covered by nature, or occupied by desperate people seeking shelter. They came across the hilly landscape of Albania, painting almost every picture in the small $28,000 \mathrm{~km}^{2}$ of small country (Raino 2017).

Twenty-five years after the fall of dictatorship, some of these formerly dominant elements of Albanian life were thought to be exposed to the public and future generations (Raino 2017; Klauzeviç 1995).

As such, some of these bunkers or buildings used by the communal nomenclature, during that time, for military or espionage purposes, were turned into museums. Their opening had to show the physical, technological, and emotional state of these objects of collective memory (reference). Inside they would have to show fragments of history, intertwined with the exhibition spaces inside them. Below we will talk about four projects of these categories. Three of them have been realized, and are in Tirana, and one of them is still unrealized, located in Vlora (Rregullore e objektit tip Tunel 1965).

In Tirana, there are three recently opened museums, of which the first two are underground military galleries,

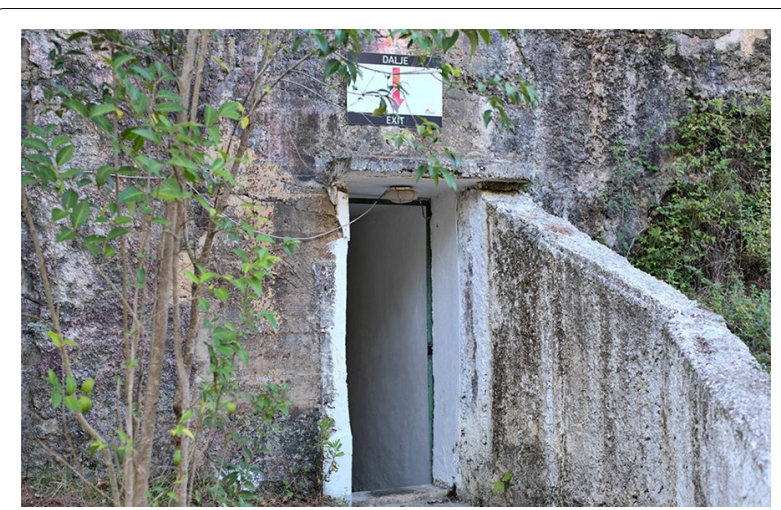

Fig. 4 Picture of bunkart external context of Bunkart 1

similar in every respect to their treatment, as well as the other museum, which was one of the main headquarters of the secret services "Sigurimi"." The Vlore Museum project, meanwhile, deals with a gallery-based military base for submarines. The names of these museums are respectively:

- The first, BunkArt 1, is located on the outskirts of the city of Tirana.

- The second, BunkArt 2, is located in the heart of the city of Tirana, directly on Skanderbeg Square, behind the Albanian state ministries.

- The House of Leaves museum near the central square

- Submarine Tunnel Porto Palermo in Vlora (Arkivi Qëndror i Ushtrisë, Buletin Arkivor Ushtarak 2011).

\section{BunkArt 1 and BunkArt 2}

Both museums have a similar physiognomy, and certainly both have been built to protect high communist political leadership in the event of an external military attack. As the name "BunkArt" implies, the two museums which are underground military galleries that already see themselves as art galleries. They are in two different points of the city of Tirana, BunkArt 1 on the outskirts and BunkArt 2 in the centre of the city.

\section{BunkArt 1}

The BunkArt 1 Museum, located in the eastern part of the city, in the Shish-Tufina area, near the General Staff Support Battalion. Although a military area, it is now accessible to the public (Fig. 4). The museum is a living testimony to the secret lives of communist leaders Enver Hoxha and Mehmet Shehu inside a tunnel they

\footnotetext{
${ }^{1}$ The mission of the Sigurimi was to prevent counterrevolutions and to suppress opposition to the regime.
} 


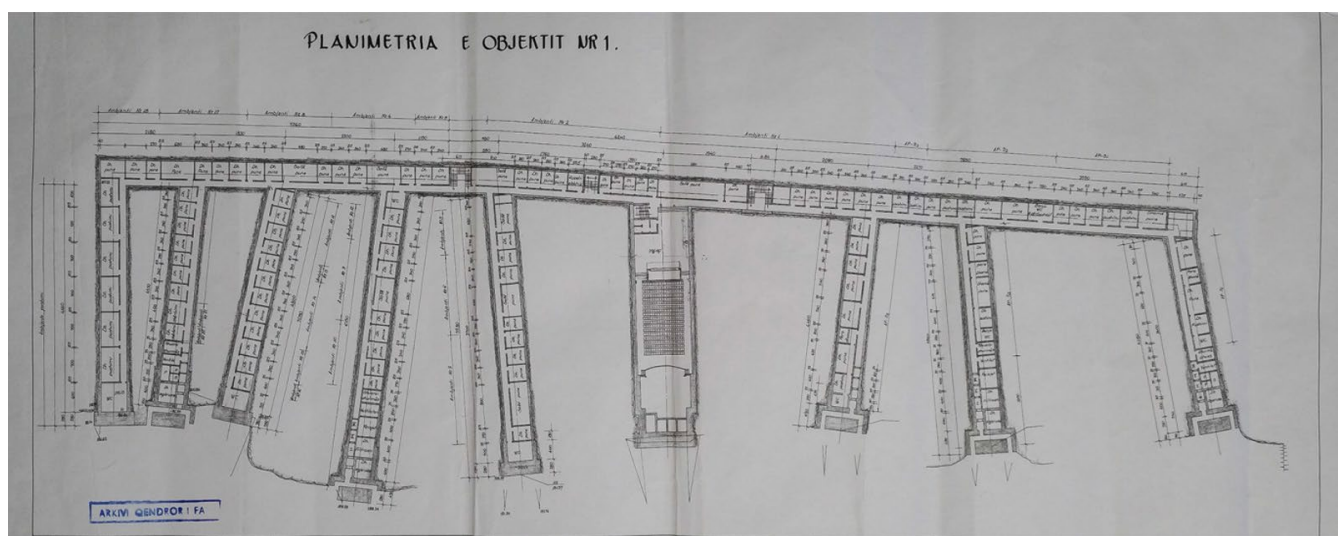

Fig. 5 Plan of existing tunnel condition of Bunkart 1

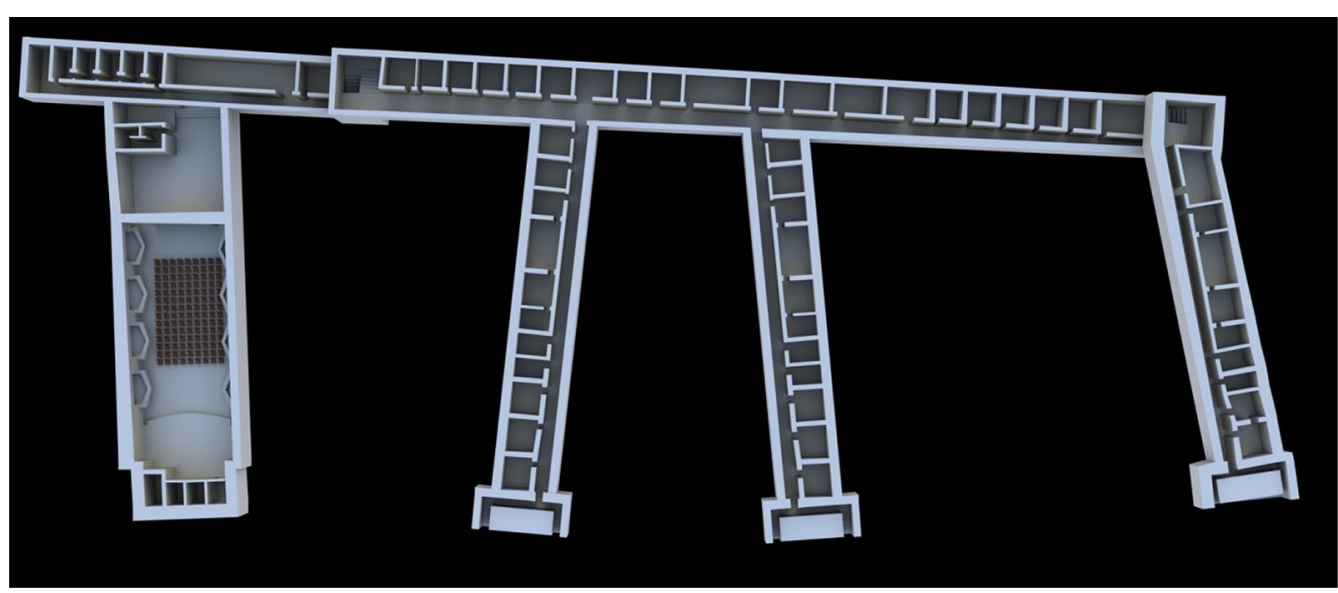

Fig. 6 Plan of the new museum Bunkart 1, curated by Carlo Bollino

created as a secret place to protect them in the event of an atomic war. BunkArt, in fact, was an anti-nuclear bunker, or more precisely an underground tunnel system, which was built in 1976. Its entrance is merged with the territory, and not very noticeable for the high military security. This tunnel system is located 5 floors underground and is composed of an amount of 106 rooms and auxiliary spaces (Fig. 5). It was built by the Communist Government with the idea of sheltering senior leadership in the event of a nuclear attack on Albania. Particular attractions are the room dedicated to dictator Enver Hoxha, and the room dedicated to the then Prime Minister Mehmet Shehu. While inside this underground bunker, there is also a large hall with 150 seats, which would be the underground hall of the Albanian parliament. The bunker has 5 armoured doors at its entrance, named after the years of communist rule, as "Objekti 0774" (Fiçorri 2002).
At the moment, this work of military engineering has turned into a Cold War Museum, where the tunnels and other physical environments are the exposed part of it. The anti-nuclear tunnel system transmits an unusual message and is named BunkArt. It was opened in 2014, on the 70th anniversary of the liberation of Albania. The internal organization left intact, reveals through many expressive forms the messages that are transmitted within it. It symbolizes the isolation of communist Albania, but also the ongoing confrontations between the communist bloc and the West during the Cold War (Fig. 6). The historical, museal and artistic lines come together to convey to visitors' clear messages about the two most discussed periods of Albanian history, the period of World War II and that of the communist regime in Albania (Premçi 2003; Voshtina 2009; Alibali 2001).

The museum is still guarded by military forces, and this military presence makes even more prosecution of the time feel. Meanwhile, to make it soluble, it is 

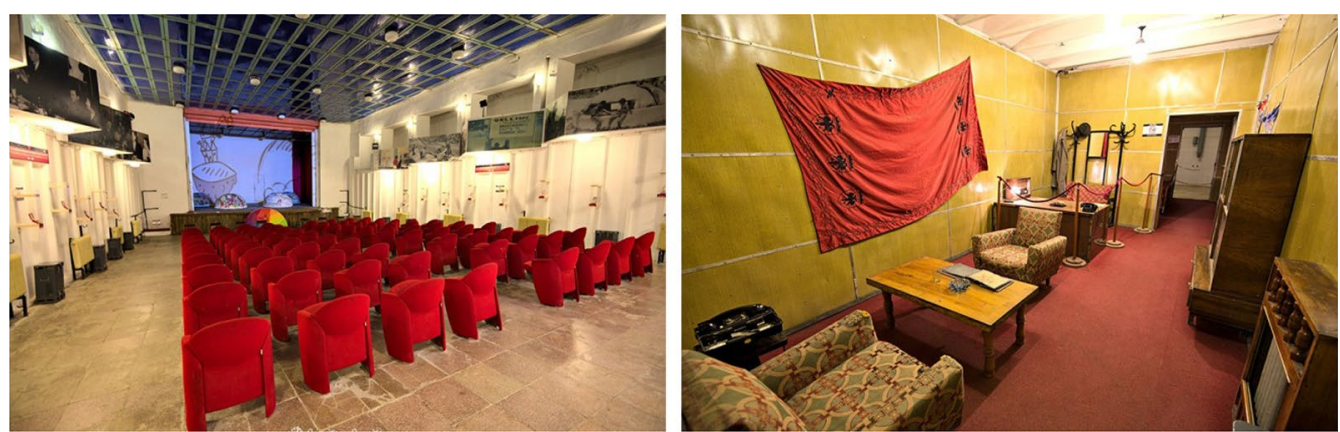

Fig. 7 Photos from the interior of the museum Bunkart 1, curated by Carlo Bollino
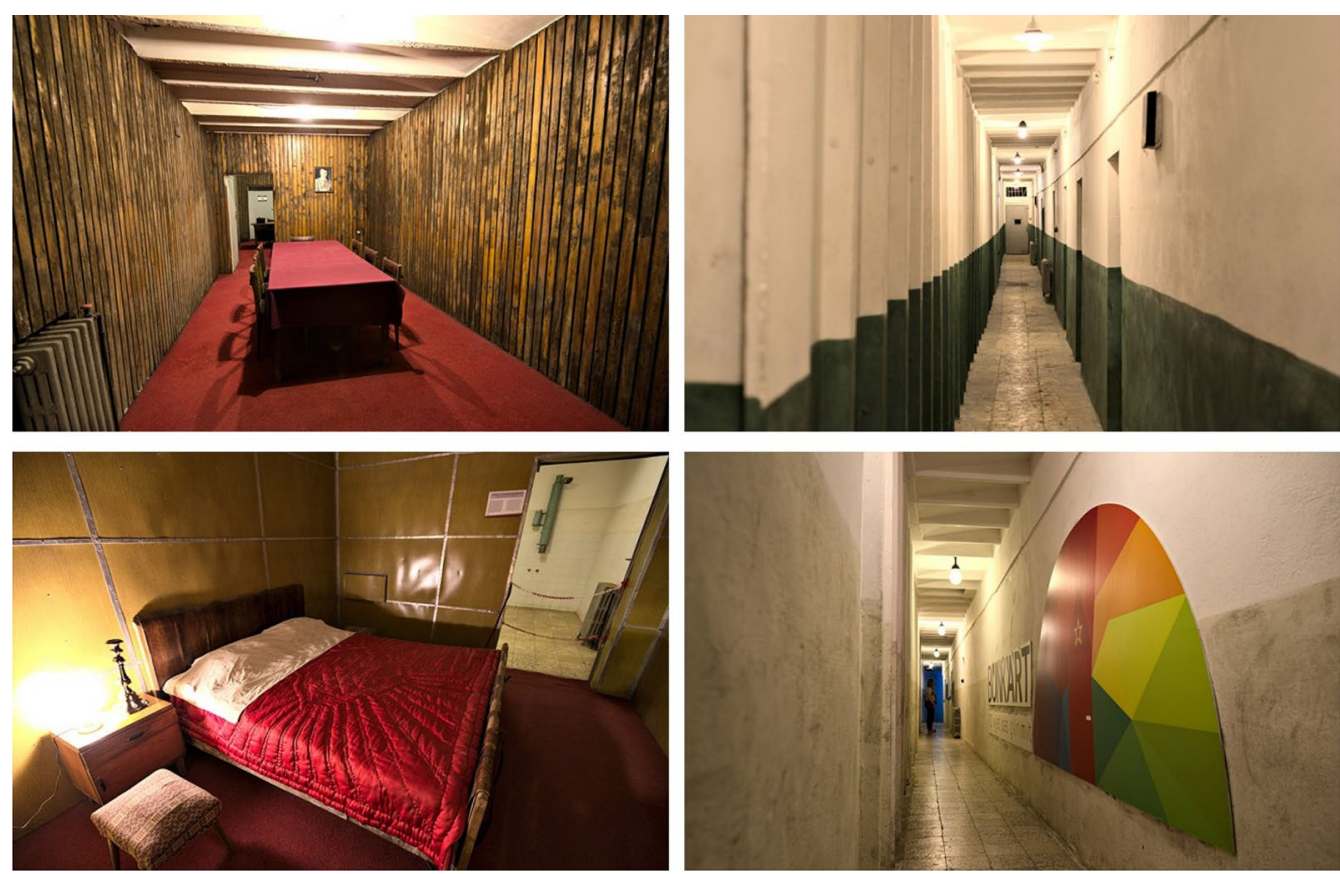

Fig. 8 Photos from the interior of the museum Bunkart 1, curated by Carlo Bollino

interfering with selected elements of the images from all the important periods of history, not only during communism (Fig. 7). The museum tends to show historical fragments, sideways of the totalitarian periods, to intertwine the link between the construction of the anti-nuclear bunker and the historical continuity of Albania (Fig. 8).

In many of these areas are exposed, weapons, uniforms, documents, maps and other details which served at that time. These relics have been inherited from the army of the Albanian communist state. The mode of presentation is attempted to have a graphic language associated with periods, and with an artistic force of expression (Moisiu 2012; Foppiano 2011).

\section{BunkArt 2}

BunkArt 2 is located near Scanderbeg Square, almost directly behind the ensemble of ministries built in the 1930s by Italian architects. It was transformed into a museum, 2 years after the opening of BunkArt 1, with a focus of attention on the victims of the communist dictatorship. This was related to the fact that the galleries of this museum during the dictatorship had to do physically and functionally with the adjacent building which was the Ministry of Internal Affairs. This institution was one of the main responsible for crimes during the communist era (Fig. 9). The presence of the underground bunker was related not only to the defence system from an external attack but was also used by the security structures of the 

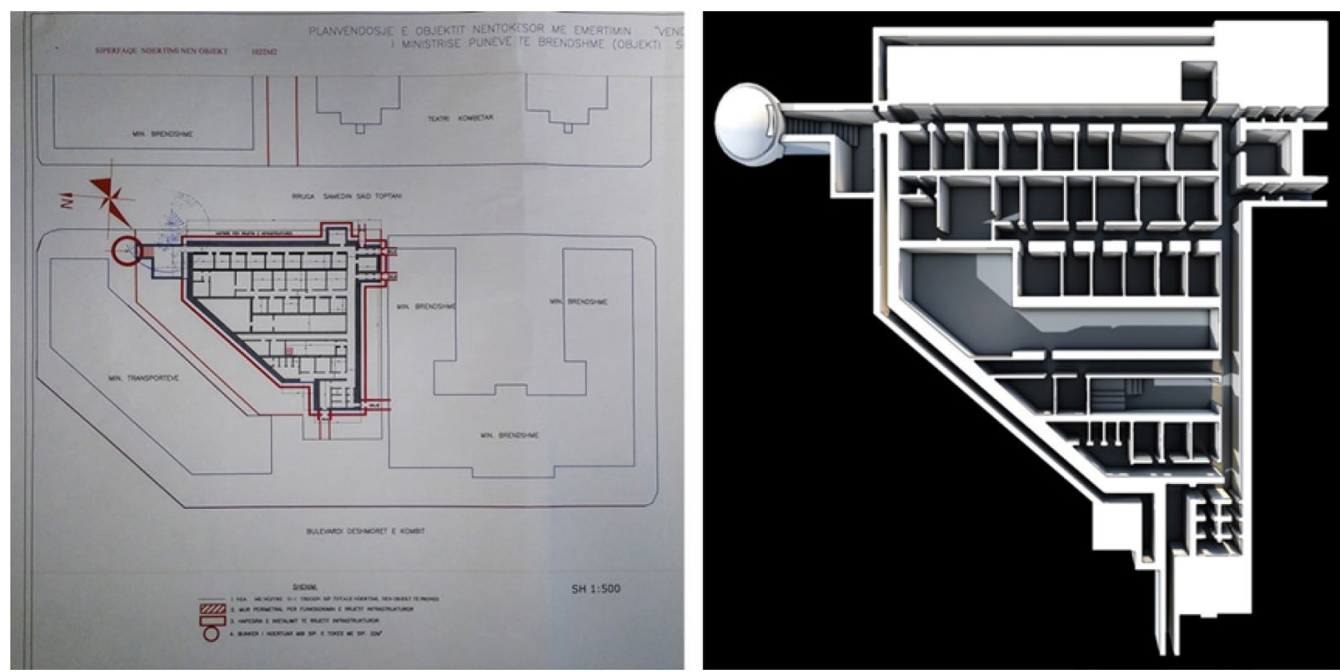

Fig. 9 Plan of existing tunnel condition and the new museum of Bunkart 2, curated by Carlo Bollino

communist state for the enemies of the system. Its construction began in 1981 and ended in 1986, 2 years after the death of dictator Hoxha. Its surface is considerable, but not as large, and as deep as BunkArt 1. Since the tunnels were connected to the ministry buildings, at the time of its transformation into a museum, some additional surface interference was carried out, adding two new volumes, which now serve the main entrance and the exit of visitors. The curators selected for the new entrance, the placement of an artificial concrete bunker according to the typology Pike Zjarri ("firing point" or PZ bunkers) (Fig. 10).

This construction of this entrance began in 2015. Apparently, the main purpose was to visualize the bunkers that the communist system was built throughout Albania. The presence of this newly constructed facility raised protests by the end of 2015, a large mass of people organized by Albanian opposition parties, in memory of 1990s anti-communist student movements in Albania. The protesters hit the bunker, built recently, and then set fire to it, leaving numerous cracks. The damaged part was left untouched, giving this part a historical character. Part of the dome, the entrance bunker, was covered with photographs of victims who were persecuted by the regime. The dome treatment looks like a replica, like Yad Vashem, the Holocaust memorial in Jerusalem, where the cylinder with this treatment is one of its main parts. In the meantime, the outside entrance was complemented by a metal guard tower, wrapped in barbed wire, installed nearby the bunker. BunkArt 2, despite the point at which it was attempted to identify itself as a museum of the victims of communism, appears in a manner very similar to that of BunkArt 1.
So, we can say that the logic of the installations artistic, with historical military, and archival material, remains the character of the museum already seen at the other museum. The interior rooms have different installations but what impresses them is the engineering work itself, as in the case of Bunk'Art 1 (Fig. 11).

\section{The House of Leaves}

In 2017, another museum dedicated to the period of communist dictatorship in Albania was inaugurated in the center of Tirana named: "The House of Leaves".

The project was curated by Studio Terragni Architetti. The project of transforming the House of Leaves into a National Museum of Secret Surveillance was initiated by the Albanian Ministry of Culture in 2014 and supported by a multidisciplinary team of historians, victims' associations, engineers, and craftsmen from different countries.

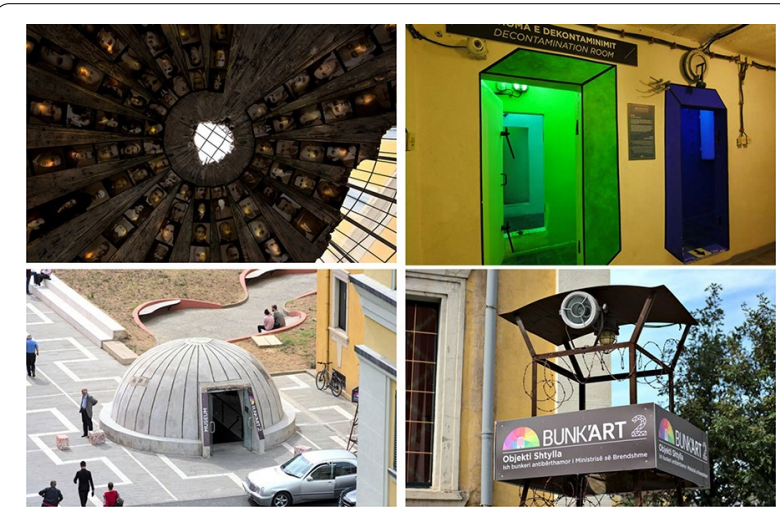

Fig. 10 Photos from the interior of the museum Bunkart 2, curated by Carlo Bollino 

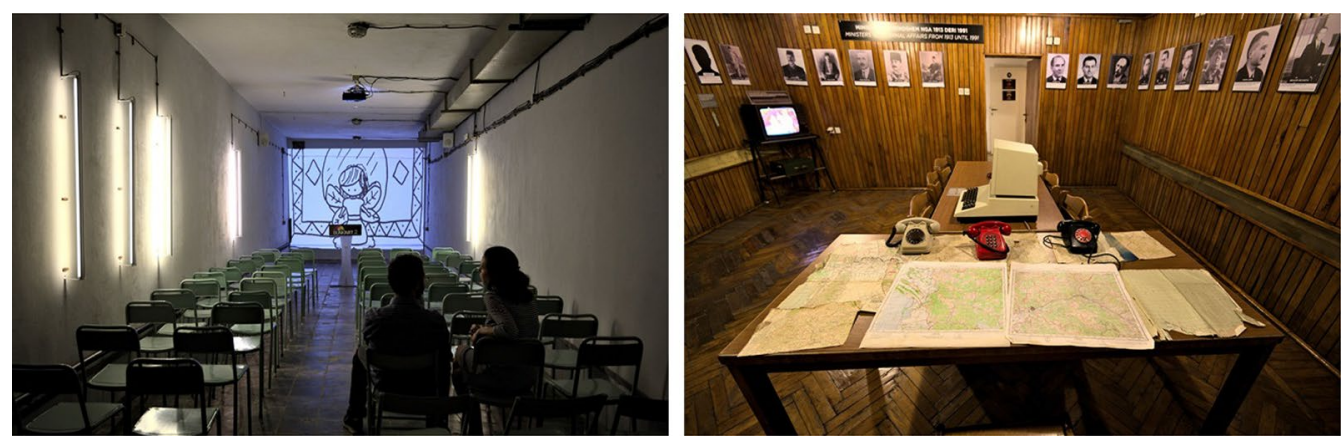

Fig. 11 Photos from the interior of the museum Bunkart 2, curated by Carlo Bollino
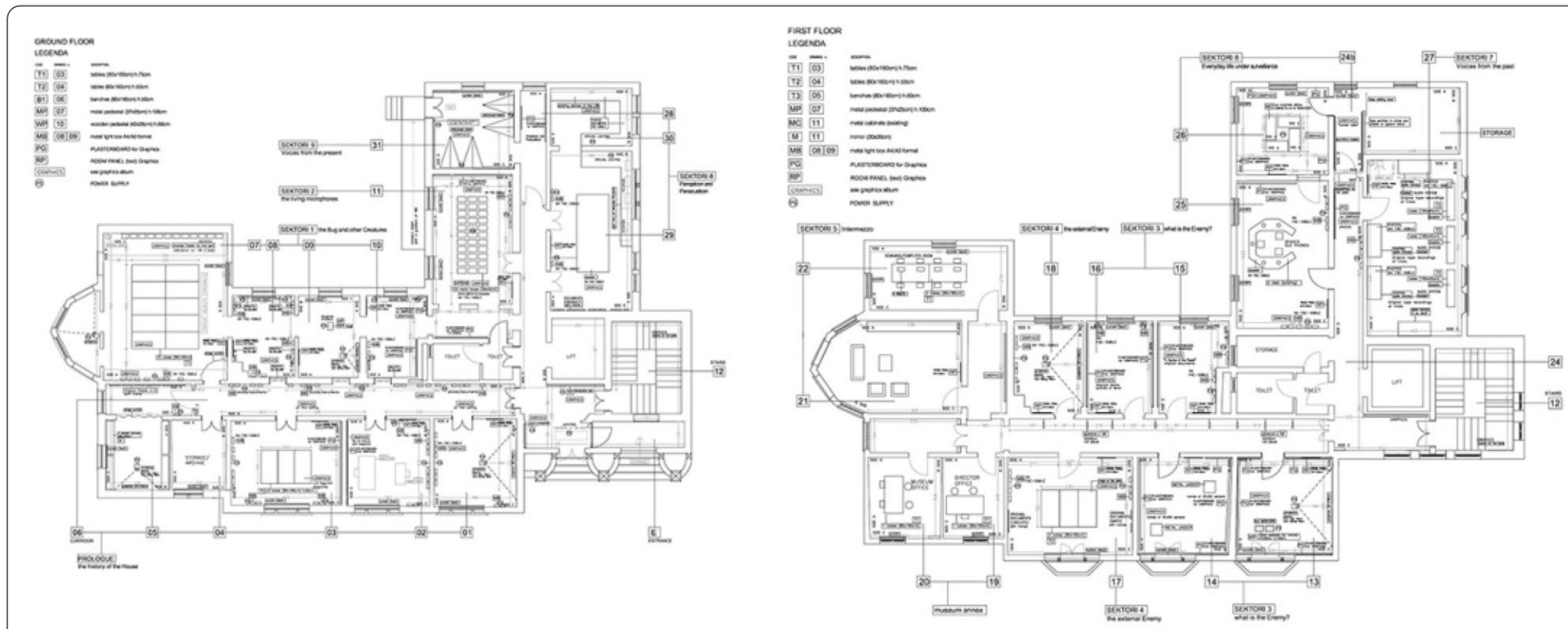

Fig. 12 Plan of ground floor and the first floor of museum is "The House of Leaves", Studio Terragni Architetti

Built in 1931, this villa has an area of over $1300 \mathrm{~m}^{2}$ and a site area of $800 \mathrm{~m}^{2}$, it was the first private obstetrics clinic in Albania. The house has a total of 31 interconnected rooms that carry within them many sad stories related to totalitarian dictatorship. The house was used by the Gestapo during World War II occupation. Later, during the communist dictatorship, the house became the headquarters of the security, the Albanian secret intelligence service. In the early days, the regime's opponents were pierced or even sentenced to death, but in later years, it was used only as a center of espionage (reference). For the time during the communism period, the building contained sophisticated equipment, and a vast network of people used to survey the life, and activity of exponents of the former wealthy class, or even of the country's most renowned intellectuals (reference). The data then passed on to the apartheid set up by the Communist Party, which in most cases made radical decisions about their lives and their families (Fig. 12).
After the 1990s, the building was abandoned for decades. The house barely looked out of the way, from the dense layer of trees and leaves, a camouflage technique normally seen in war. It also received the metaphorical name "The House of Leaves".

The museum is divided into nine sections, and the main purpose is to discover the sophisticated and advanced ways of controlling the communist state over the Albanian people. The exhibit spaces in the museum vary, some of which are dedicated to the materials contained in it: microphones and various interception technologies used by Sigurimi. Other sections of the museum display declarations, work and files prepared by state informants. The sheer volume of surveillance, surveillance and surveillance equipment reveals the startling amount of investment made by the communist state, which is unbelievable given Albania's economic situation at the time. The exhibitions portray 

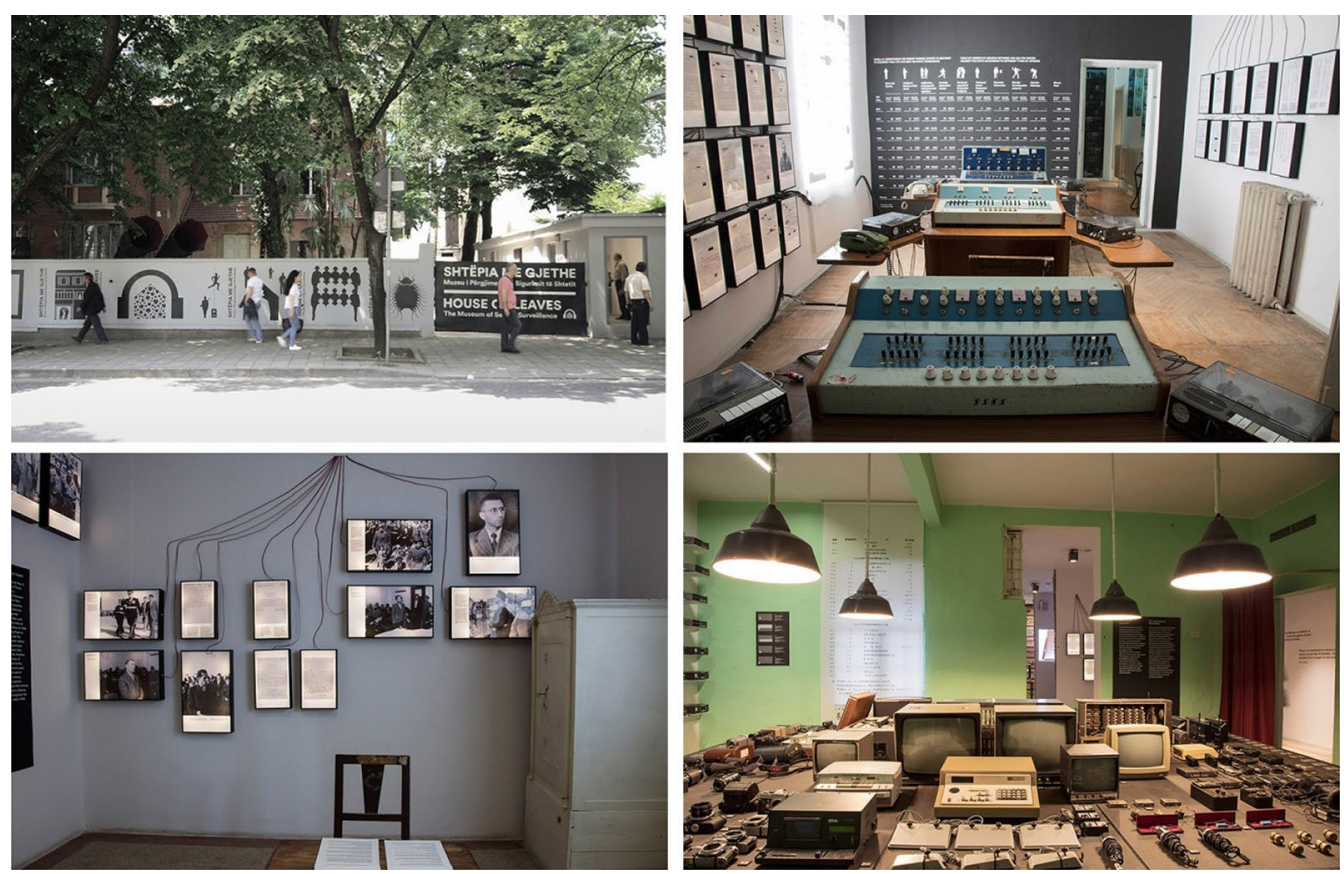

Fig. 13 Picture from the interior of the museum "The House of Leaves", Studio Terragni Architetti

a Communist perception of the enemy, external and internal, for which a great deal of state vigilance was focused.

The House of Leaves has also combined a typical Albanian interior living space of the 1970s. The "Panopticon and Panacusticon" exhibit is something akin to a science lab of secret photos, recordings and visuals, all of which add to a wild experience. audio-visual for the visitor. A multitude of emotions permeate each visitor's mind and awareness as you walk through the rooms of this museum. Its realization at the beginning was intended to show not only the historical aspect of this house, but also the ideological and poetic pressure of the time, as you try to imagine that this was a reality for the Albanians in the not-too-distant past (Neshaj 2015).

In a country that had used labour of the incarcerated in exchange for importing surveillance devices from 18 different countries, Studio Terragni Architetti decided to produce everything on site, relying on the skill of people and the low cost of materials. The total cost for 33 rooms, 800 mq. was 540.000 euros (Fig. 13).

Before entering the museum, a garden covered in convallaria japonica invites people to explore the sound of the city by handling these pre-war listening devices themselves (Fig. 14).

Visitors can gather and collect their thoughts in the backyard, sitting on two long benches, a colourful and pleasant distraction in the backyard. Walking around you soon discover that only from one point of view, marked by a read seat, do the two objects collapse into the single image of a headset, the ultimate iconic symbol of surveillance.

\section{Submarine Tunnel Porto Palermo}

Porto Palermo's military base is located in the Gulf of Panorma, about $80 \mathrm{~km}$ from Vlora. Nearby is also a monument of historic and architectural value, the Ali Pashe Tepelena Castle (Fiçori 2015) built in the XVIII century. In a spectacular panorama over the Ionian Sea, it was decided to build a naval tunnel and naval military base, worked for more than 15 years by Albanian military forces. For its realization (Engels 1976), mainly the work of soldiers and engineers who performed military service in this military area was used. Between 1955 and 1968, the Soviet Union landed 12 Soviet Whiskey Class submarines in Vlora (Hoxha 1984).

They should serve to have direct control over the Strait of Otranto (Engels 1976). The military point south of the Ionian Sea was totally strategic. After Albania withdrew from the Warsaw Pact, Hoxha appropriated all four submarines, controlled by Albanian soldiers, and placed them in Porto Palermo (Hoxha 1984). This country turned into a strong military position for Enver Hoxha (Lufta e Vlorës 1994; Politika e Sigurimit dhe e Mbrojtjes e Republikës të Shqiperise 2001). The military project's strategic design leaves the bay free and creates a 

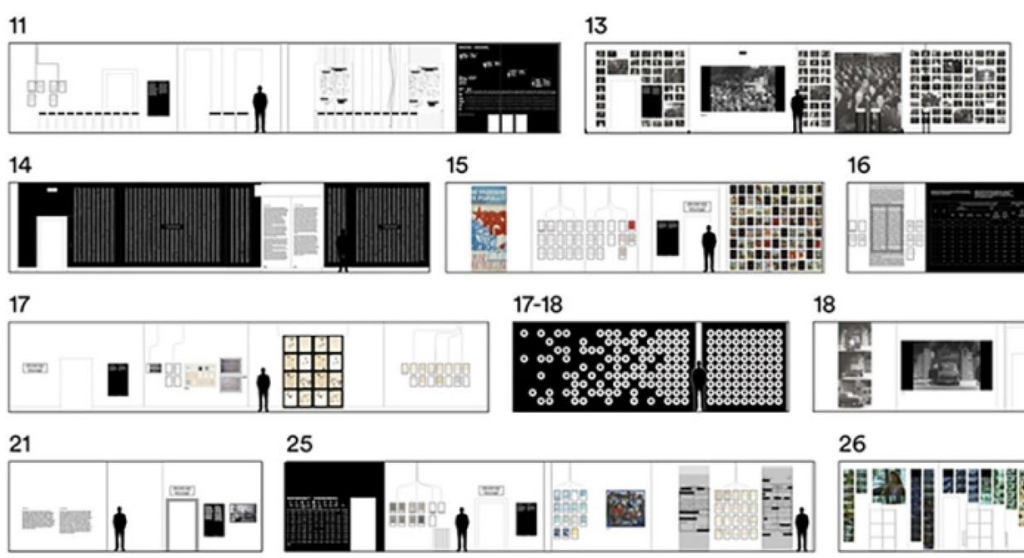

25

\section{6}
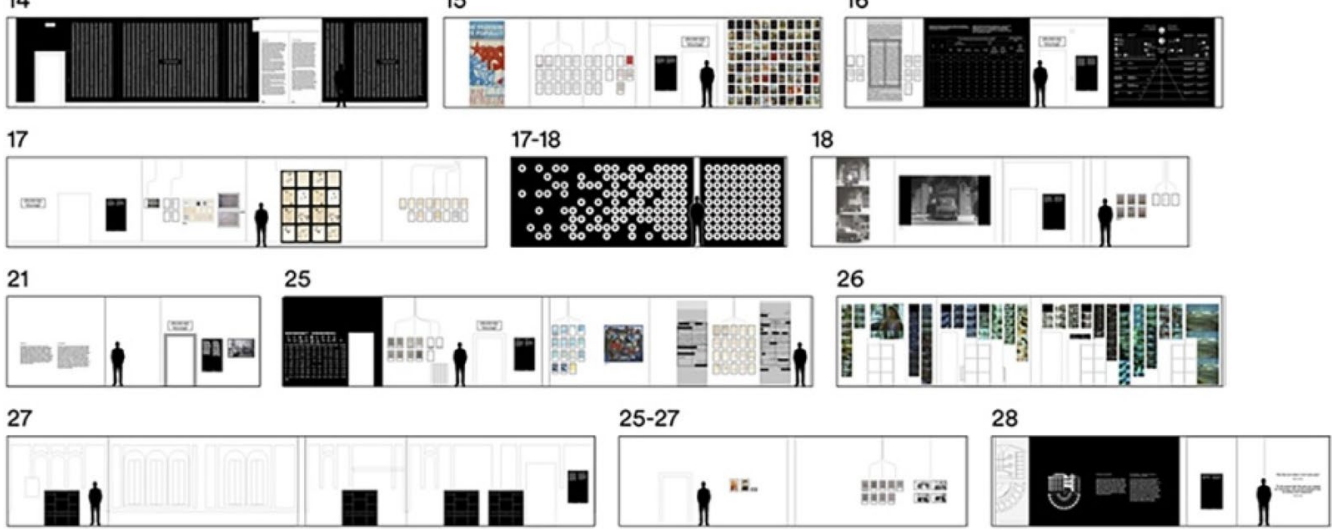

Fig. 14 The interior project of the museum "The House of Leaves", Studio Terragni Architetti
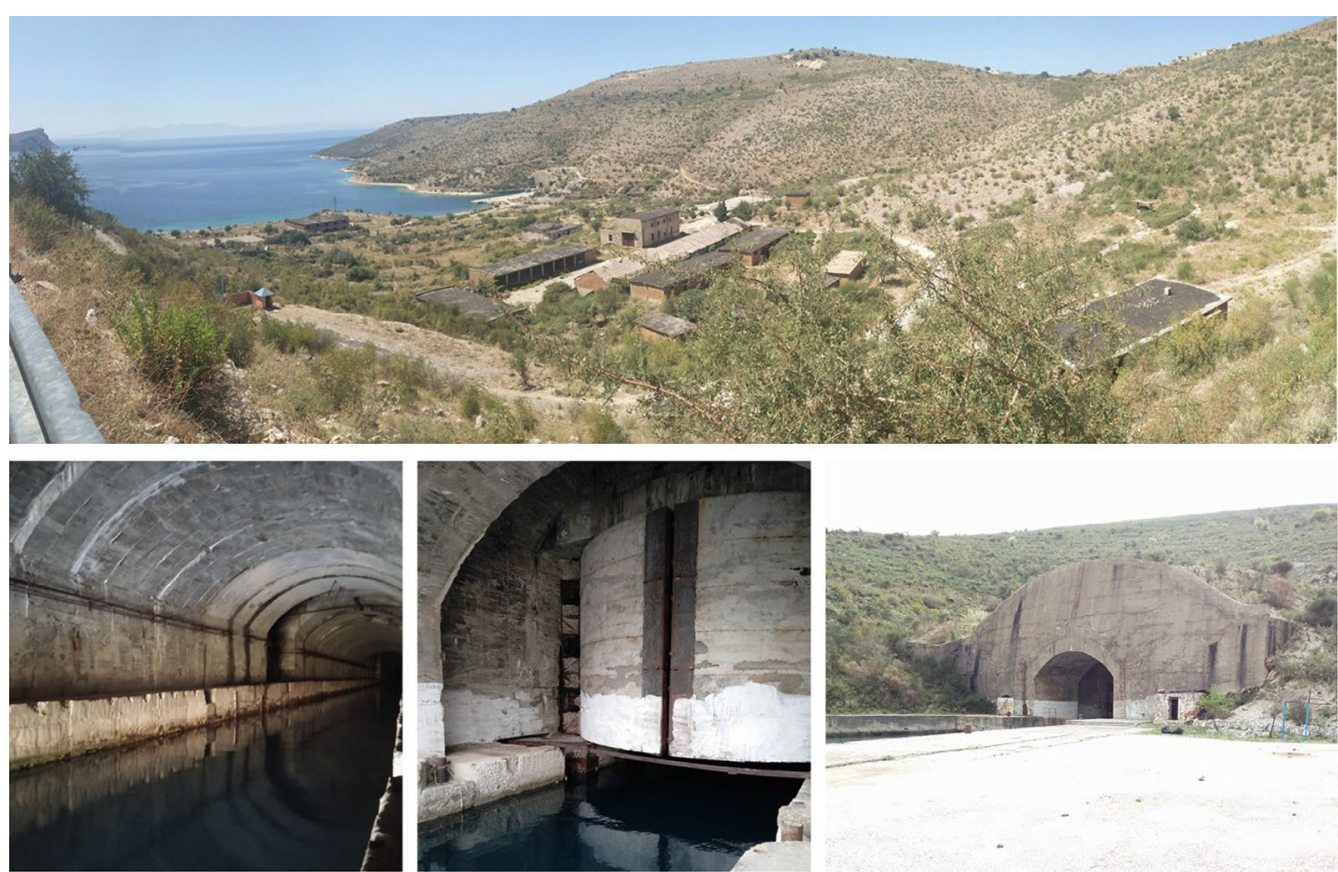

Fig. 15 Picture from the existing situation of Porto Palermo's military base, Photo by Debora Bilani

long, straight tunnel on the small peninsula. Thus, began the construction of a $650 \mathrm{~m}$ long, 12-m-high tunnel dedicated to submarines. Four submarines were placed inside it, one after the other. The rock formation was made so that the exterior of the tunnel did not look out of the sea (Engels 1976). The tunnel is a giant engineering feat, which has a host of secondary barracks-type military facilities, as well as a host of small, bunkers spread throughout the territory (Fig. 15). Even the military base itself has been abandoned, for a long time, and now we are talking, it consists only of rubble, it is not possible to get into the facility. The Albanian Coast Guard uses it as a base on the coast and preserved undisturbed rest of the surrounding terrain (Arkivi Qëndror 


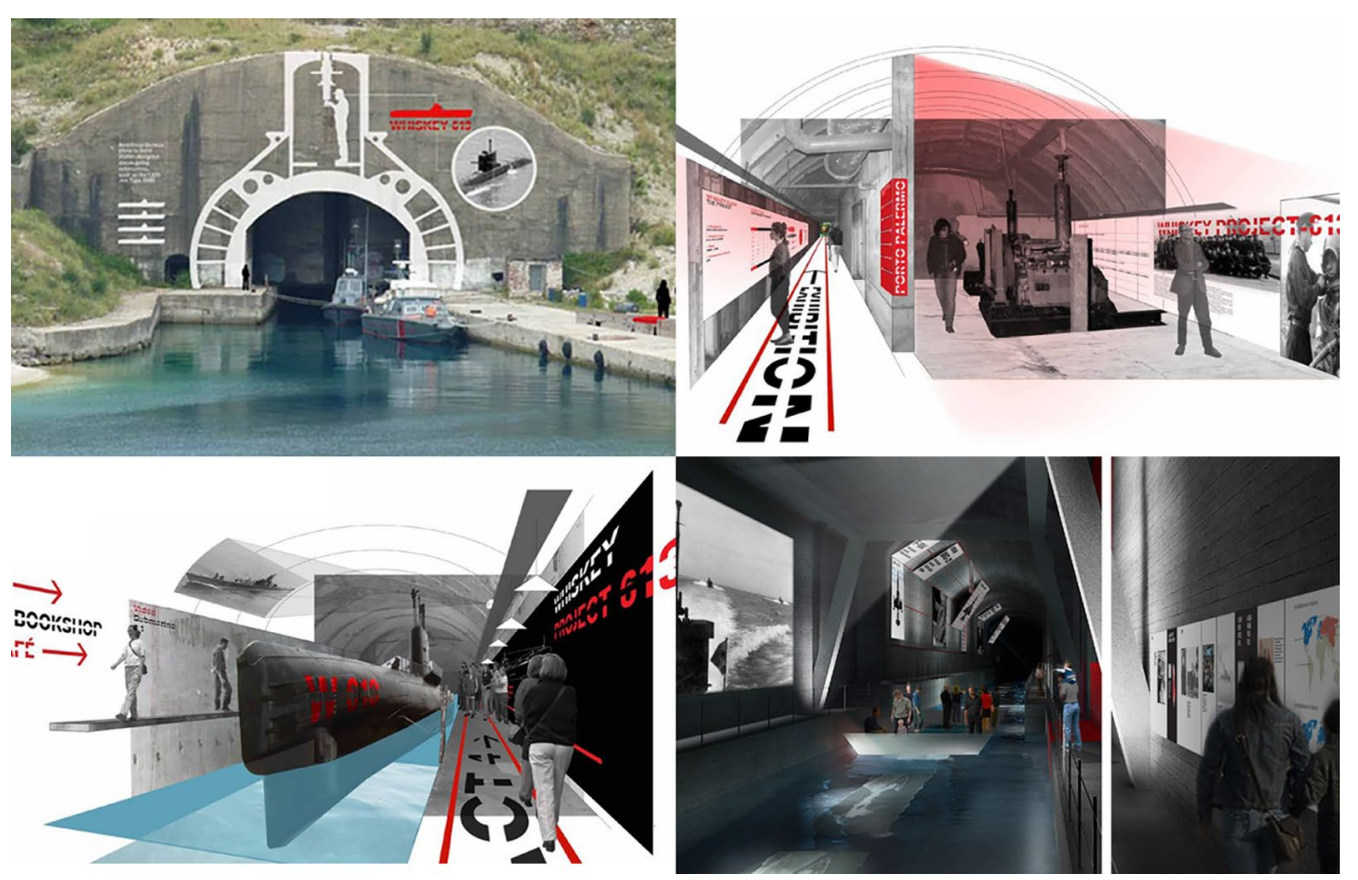

Fig. 16 The interior project of the museum "The Submarine Tunnel Porto Palermo", Studio Terragni Architetti

i Ushtrisë, Buletin Arkivor Ushtarak 2011; Rregullore të Fortifikatës fushore 1952; Vjet Akademie Mbrojtjes 2008).

The Submarine Tunnel Porto Palermo, from its opening in 1986 until 1993, served as the base of the Submarine Brigade. The construction of the base started in about 70 years and its construction took almost 17 years. Initially the base was planned to be built as the base for four rocket ships that were planned to be taken from China. The latter never materialized, so the base was adapted for submarines (Hoxha 1984; Stefa and Mydyti 2009). From 1993 to 2004, the Palermo base served as a reserve base of the Second Marine District, occasionally under the control of the Commando Regiment (Moisiu 2012).

At the present state, the museum, has not yet been realized, but the idea of transforming it is a good base to return to, following the example of the first three. There are several projects of public interest for this. One of the first ideas to turn this military space into a Cold War Museum was once again commissioned by architects Elisabetta Terragni and Jeffrey Schnapp (Fig. 16). They had successfully designed and implemented a few years ago, something analogous, in Trento, Italy. It was also about an underground museum existing gallery in Trento, had been part of the western ring road of the city, but after the construction of two new galleries, they were back in August 2008 in a museum space devoted mainly to the history and memory.
In the project for the Porto Palermo Military Base, the tendency to treat it is the same as seen in the BunkArt project in Tirana. So, making a direct link to the past, by leaving out as many traces as possible, of the history of the tunnel itself. In the meantime, besides the physical space of the concrete tunnel, the project also puts underwear, which also adds to the excitement of the museum. While from the point of view of the presentation of its historical, but also historical pieces, it is played with materials and contemporary elements of museography, or even graphics, to bring to the visitor the atmosphere of time. The project extends the museum across the $650 \mathrm{~m}$ tunnel. An important part of it, are the graphic elements placed at the museum's entrance, which explain the first infotainment regarding the interior. The project had a resonance in various publications as well. There is also a quote from "Abitare" magazine, which dedicated a study by Anna Foppiano on concrete fences in Albania, and on the Terragni project in Porto Palermo (Neshaj 2015).

It says: "The submarine base for submarines (a 650-foot-long, 12-foot-high tunnel for 4 Whiskeys, $90 \mathrm{~m}$ each) cutting a strip of land in Porto Palermo, or more specifically in the Bay of Panorma, is definitely an extraordinary place, between water and heaven, to consider, document and transmit Cold War events." (Hoxha 1984).

The Porto Palermo Tunnel has been an object of great interest, even for architecture students, at the Polytechnic 


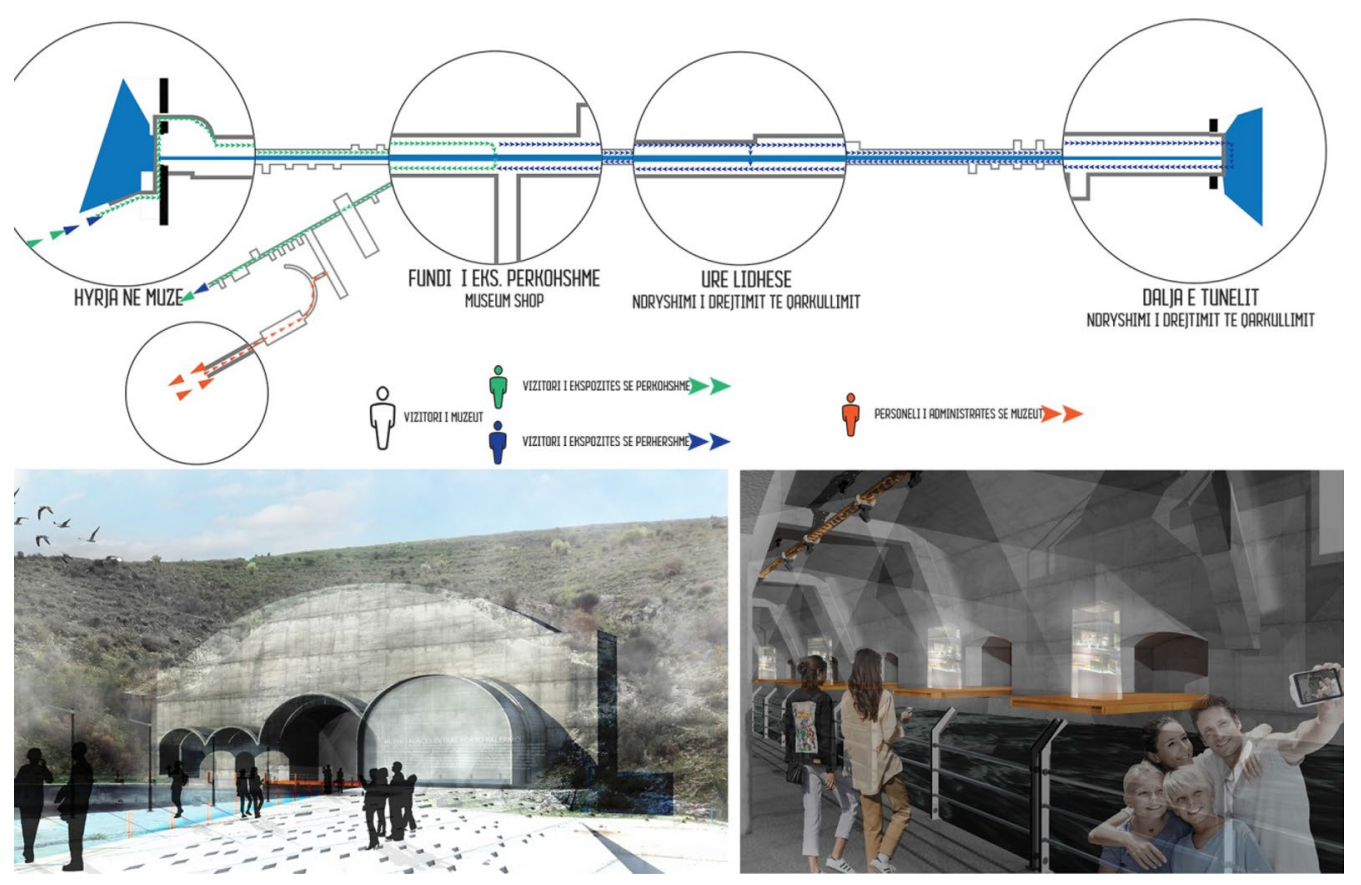

Fig. 17 The interior project of the museum "Porto Palermo's military base", diploma thesis of Debora Bilani

University of Tirana. There have been some diploma topics, related to the tunnel, and to the surrounding area (Fig. 17), dealing not only with the underground tunnel but also with buildings and captains military built in outer space. While studying the basic concept, it was important to come up with a multifunctional system that would give the museum more functionality than just a glimpse of its historical part. Especially taking advantage of the summer tourist area, where tourists who visit the area periodically can return to this museum from time to time. The part of the degraded military buildings outside, under this project, was subject to restoration and completion for new functions.

\section{Conclusion}

Conceptually, we can say that all four museums have many similar elements. The main unifying idea is that, after a quarter of a century, after the fall of communist dictatorship, to realize and feel the intense pressure of time, even though the wounds caused by it are still fresh. What is attempted in the first place is a direct visit to the premises where the most extreme points produced by the totalitarian system, linked to the military, and espionage, were focused [54]. They are thus left, as intact as possible, to perceive, during their visit, at any point, the direct connection of historical memory with its spatial interpolation. So, this remains the main museum graphic element. Second is the tendency to reflect through images, photos, archive materials and various military tools part of the country's history. The tendency to translate it into an artistic form sometimes attenuates the strong emotion that the pristine environment can convey.

One shortcoming, which can be fulfilled a second time, is finding the premises, to have the opportunity to be completed with temporary exhibitions, or various events, to absorb the visitors who have once been inside. Their spaces are very special and attractive to promote other events of historical or artistic character. The paranoia of the dictator and members of the Political Bureau of the Communist Party in Albania has tried, besides spatial experience of different environments, to bring with it different installations. The trend, especially in BunkArt museums 1 and 2, is the contrast between the invisible pressure of time and the paranoia of power, aligned in many intertwined ways. However, another element to be felt would be more of a concrete connection within the underground tunnels, and thousands of bunkers, where like mushrooms sprout in the landscape of Albania during the totalitarian dictatorship.

\section{Acknowledgements \\ None.}

\section{Authors' contributions}

$\mathrm{AV}$ conceived of the presented idea. AV and ES developed the theory and performed the analysis. All authors verified the analytical methods and supervised the findings of this work. All authors discussed the results and contributed to the final manuscript. All authors read and approved the final manuscript. 


\section{Funding}

No funding to declare

\section{Availability of data and materials}

The authors can provide readers with information about the research data required to reproduce the work reported in the manuscript.

\section{Declarations}

\section{Competing interests}

The authors declare that they have no known competing financial interests or personal relationships that could have appeared to influence the work reported in this paper.

\section{Author details}

${ }^{1}$ Faculty of Architecture and Urbanism, Politecnical University of Tirana, Rruga Muhamet Gjollesha 56, Tiranë, Albania. ${ }^{2}$ Faculty of Civil Engineering, Polytechnic University of Tirana, "Nene Tereza" Square No.4, Tiranë, Albania. ${ }^{3}$ Faculty of Architecture and Engineering, Epoka University, Rruga Tiranë-Rinas, Km 12 , 1039 Tiranë, Albania.

Received: 2 May 2021 Accepted: 31 October 2021

Published online: 23 November 2021

\section{References}

Agolli A (2012) Kualifikime shkecore në Forcat e Armatosura 1974 Alibali B (2001) 50 Vjet mbi mina botim

Arkivi Qëndror i Ushtrisë, Buletin Arkivor Ushtarak (2011)

Biaggini A (2005) Storia dell'Albania contemporanea. Bompiani, Milano, pp $136-138$

Bullen PA, Love PED (2010) The rhetoric of adaptive reuse or reality of demolition: views from the field. Cities 27(4):215-224

Bullen PA, Love PED (2011) Adaptive reuse of heritage buildings. Struct Surv 29(5):411-421

Cerreta M, Elefante A, La Rocca L (2020) A creative living lab for the adaptive reuse of the morticelli church: the small project. Sustainability (switzerland) 12(24):1-20

Cooper I (2001) Post-occupancy evaluation-where are you? Build Res Inf 29(2):158-163

Diamonstein B (1978) Buildings reborn: new uses, old places. Harper \& Row Publishers, New York

Dokument i deklasifikuar i Ministrise se Mbrojtjes se Shqiperise (1984) D.nr. 7 . F. 5

Engels F (1976) Vepra të Zgjedhura Ushtarake. Tiranë |-Il:353

Fabrizio G, Maria GZ (2010) Concrete mushrooms, Abitare

Fiçori R (2015) Historia e armes se genios ne Shqiperi. ILAR, Tirane

Fiçorri F (2002) Ushtritë e Huaja në Shqipëri, Tiranë

Foppiano A (2011) Albania: riavvolgere la bobina della memoria

Golloshi M (2010) Fortifikimi Shqiptar i Shek. XX (Vështrim historik) botim

Gosling J, Sassi P, Naim M, Lark R (2013) Adaptable buildings: a systems approach. Sustain Cities Soc 7:44-51

Günçe K, Misirlisoy D (2014) Adaptive reuse of military establishments as museums: conservation vs. museography. In: Passerini G (ed) WIT transactions on the built environment, vol 143. WITPress, Southampton, pp 125-136
Guxholli B (1981) Shqiperia Shkemb Graniti Tiranë

Guxholli B (1988) Sigurimi xhenier në shekuj, Tiranë

Hasnain H, Mohseni F (2018) Creative ideation and adaptive reuse: a solution to sustainable urban heritage conservation. In: IOP conference series: earth and environmental science, Vol 126, Institute of Physics Publishing History of Army War Art (1989) Vol 2, pp 228-229

Hoxha (1984), Për Ushtrinë Popullore, botim

Hunter JW, Jateff E (2016) From battleship to breakwater: post-military adaptive reuse of the Australian warship Protector. Int J Naut Archaeol 45(2):423-440

Hutchings R (1997) American diplomacy and the end of the cold war. Woodrow Wilson Center Press, Washington, DC, p 261

Karaiskaj GJ (1990) 5000 vjet fortifikim shqiptar

Klauzeviç K (1995) "Mbi luften", vellimi i dytë botim shqip

Latham D (2000) Creative reuse of buildings. Donhead Publishing, Shaftesbury

Lleshi S (2020) Udhëheqja ushtarake globalizimi dhe rasti i Shqipërisë. Onufri, Tirana

"Lufta e Vlorës" botim, 1994 Arti Ushtarak Popullor, botim 1971 dhe ribotim 1976

Martínez-Molina A, Tort-Ausina I, Cho S, Vivancos JL (2016) Energy efficiency and thermal comfort in historic buildings: a review. Renew Sustain Energy Rev 61:70-85

Misirlisoy D, Günçe K (2016) Assessment of the adaptive reuse of castles as museums: case of Cyprus. Int J Sustain Dev Plan 11(2):147-159

Moisiu A (2012) Kujtime volumi II-të

Neshaj SA (2015) Sazani - Ishulli i perendive. Mirgeeralb, Tirana

Pintossi N, Ikiz Kaya D, Pereira Roders A (2021) Identifying challenges and solutions in cultural heritage adaptive reuse through the historic urban landscape approach in Amsterdam. Sustainability (switzerland) 13(10):5547

Politika e Sigurimit dhe e Mbrojtjes e Republikës të Shqiperise, botim 2001

Premçi V (2003) Kapiteni që luante me vdekjen, Tiranë

Raino I (2017) An itinerary of the creative imagination: Bunk'Art and the politics of art and tourism in remembering Albania's Socialist Past

Rregullore e objektit tip Tunel (1965)

Rregullore të Fortifikatës fushore, botim 1952

Shametaj I (2004) Ndërlidhja nga engjelli e profeti tek internet

Stefa E, Mydyti G (2009) Concrete mushrooms: bunkers in Albania. Politecnico di Milano, Milan

Stubbs M (2004) Heritage-sustainability: developing a methodology for the sustainable appraisal of the historic environment. Plan Pract Res 19(3):285-305

Tweed C, Sutherland M (2007) Built cultural heritage and sustainable urban development. Landsc Urban Plan 83:62-69

Vjet Akademie Mbrojtjes botim 2008

Vokshi A (2020) Tirana arkitektura 1920-2020. GentGrafik, Tirana

Voshtina F (2009) Industria Ushtarake, Tiranë

Wilkinson SJ, James K, Reed R (2009) Using building adaptation to deliver sustainability in Australia. Struct Surv 27(1):46-61

Yazdani Mehr S, Wilkinson S (2020) The importance of place and authenticity in adaptive reuse of heritage buildings. Int J Build Pathol Adapt 38(5):689-701

\section{Publisher's Note}

Springer Nature remains neutral with regard to jurisdictional claims in published maps and institutional affiliations. 